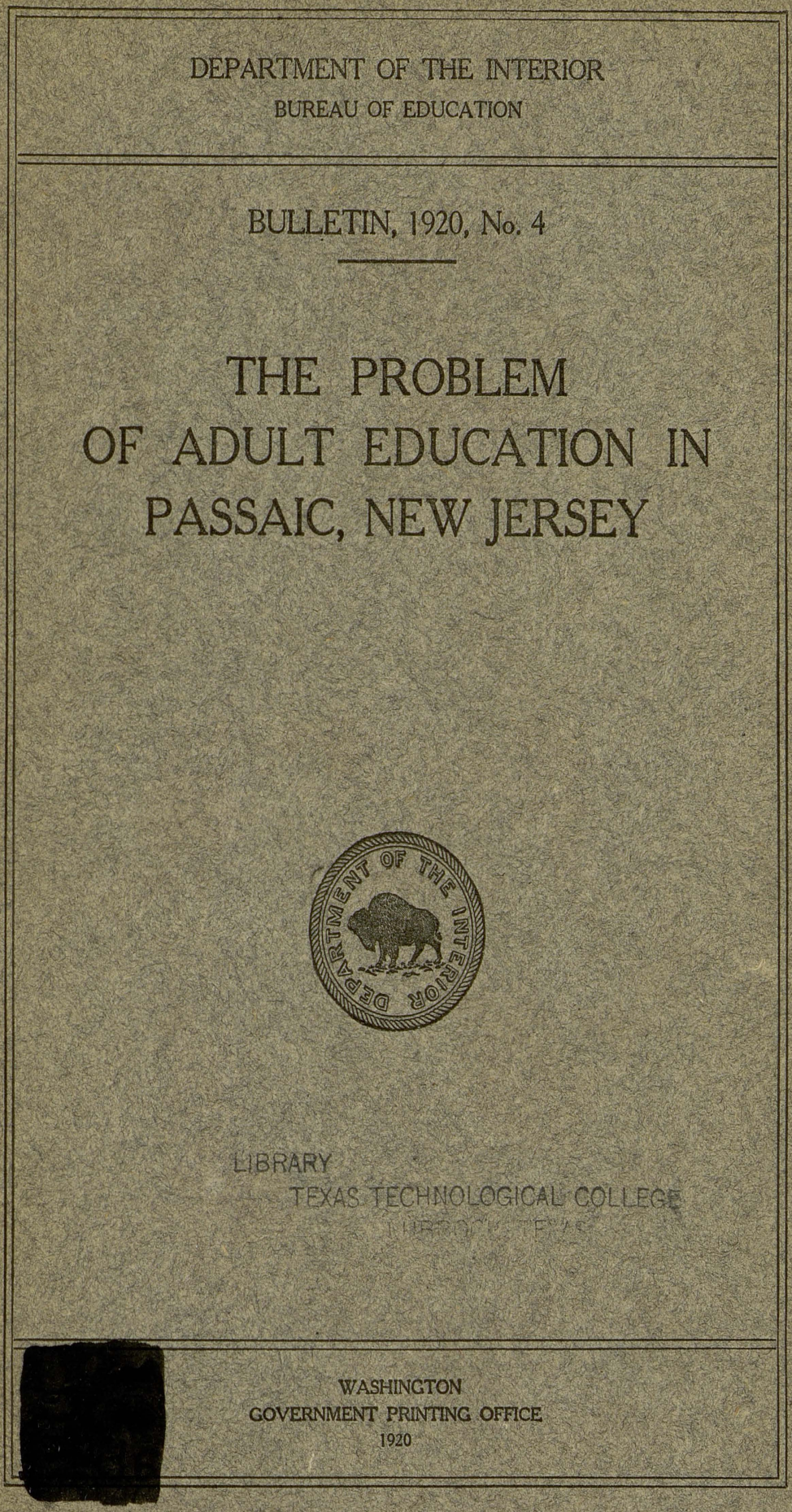


TEXAS TECH UNIVERSITY

|||||||||||||||||||||||||||||||||||||||||||||||||||||||||||||||||

31295025587170 
DEPARTMENT OF THE INTERIOR

U.S, BUREAU OF EDUCATION

v

BULLETIN, 1920, No. 4

\title{
THE PROBLEM \\ OF ADULT EDUCATION IN PASSAIC, NEW JERSEY
}

\author{
LIBRARY \\ TEXAS TECHNOLOGICAL COLLEGE. \\ LUBBUCK, TEXAS
}


ADDITIONAL COPIES

OF THIS PUBLICATION MAY BE PROCURED FROM THE SUPERINTENDENT OF DOCUMENTS GOVERNMENT PRINTING OFFICE WASHINGTON, D. C.

AT

10 CENTS PER COPY 


\section{Department of the Interior, BuRead of Education, Washington, January $26,1920$.}

SIR: At the request of the Board of Education of the City of Passaic, N. J., this bureau has recently made a comprehensive study of the problem of adult education in that city. The study was made by Mrs. Alice Barrows Fernandez, specialist in social and industrial relations and education, detailed for this purpose by me. The finding of this study, together with constructive recommendations, I am transmitting herewith for publication as a bulletin of the Bureau of Education. Since Passaic has a very large foreign population and a very large percentage of illiteracy, third among the cities of the United States in this respect according to the census of 1910, this report will be of value to all persons interested in the problems of Americanization and the teaching of illiterates. Permit me to call attention to the fact that Mrs. Fernandez has treated somewhat fully the relation of adult education to the industrial life of the city and has emphasized the fact that Americanization is very largely a social problem.

Respectfully submitted.

\section{P. P. Claxton,} Commissioner.

The honorable the SECRETARY OF THE INTERIOR. 


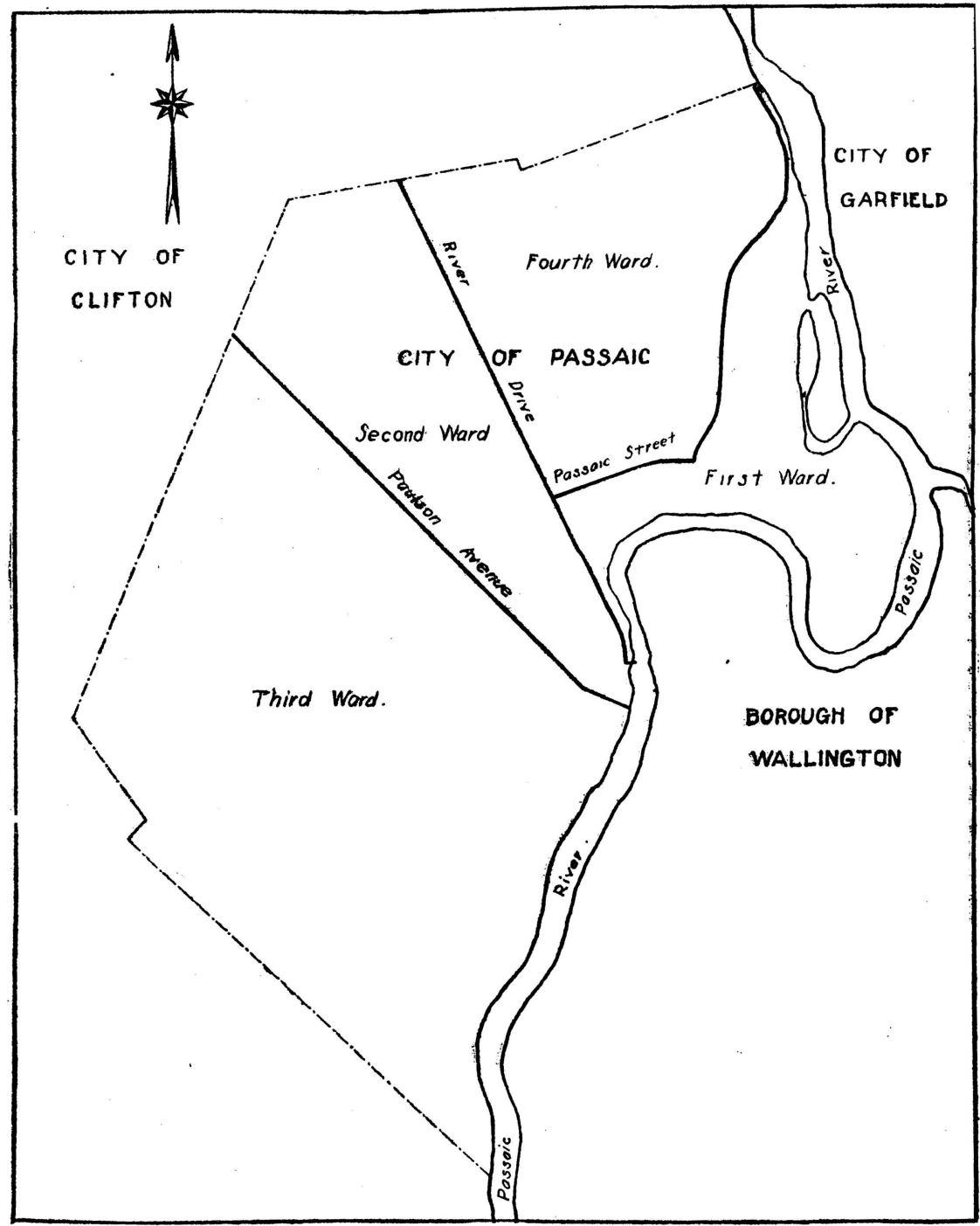

MAP OF THE CITY OF PASSAIC, N.J.

"In Passaic 22,266 people, or 40.6 per cent of the total population, llved in Ward 1-one-sixth the total area of the city (280.5 acres); while 5,411 people, or 9.9 per cent, llved in Ward 3, i. e., in nearly one-half the total area of the city $(783.9$ acres $) . "-S e e$ p. 6. 


\section{THE PROBLEM OF ADULT EDUCATION IN PASSAIC, N. J. ${ }^{1}$}

Owing to the character of the population and the industrial situation in Passaic, N. J., the city has an opportunity to make a contribution to the problem of adult education which should be significant for all industrial cities in the country. But there are certain fundamental difficulties inherent in her present industrial and social conditions which will have to be recognized before any adequate system of adult education can be started.

The Bureau of Education, in conducting the survey of adult education in Passaic, began with a survey of the general social and industrial conditions of the community in order to determine the need for adult education. Obviously, since the public schools were created by the people for the use of all the people, it is necessary in making an estimate of any educational system to determine in the first place the needs and desires of the people. Important as this is in the matter of day-school education of children, it is doubly so in the study of adult education, for, while elementary-school education is compulsory, the attendance of adults at day or evening school is optional, and the very existence of the classes depends on the effectiveness of the schools in meeting the needs and desires of the people. Adult education is one of the few types of public education which has to meet the test of making good from day to day, or from night to night, with the people who come to the classes. Consequently, in studying adult education in Passaic, it is a matter of the first importance to know who the people of Passaic are-what is their nationality, where and how they live, in what kind of industries they work, how many hours they work, what their desires are in regard to education, to what extent they are using the public schools, and what are their criticisms of the schools.

\section{SOME SOCIAL AND INDUSTRIAL FACTS ABOUT PASSAIC.}

Passaic is a city of approximately 60,000 to 70,000 inhabitants, $^{2}$ so hemmed in by the surrounding towns of Clifton, Garfield, and Wall-

\footnotetext{
${ }^{1}$ In October, 1919, upon the request of the Board of Education of Passaic, N. J., the United States Bureau of Education undertook an investigation of the problem of adult education in that city. The Commissioner of Education detailed Alice Barrows Fernandez, the bureau's specialist in social and industrial relations in education, to carry on the work, which was begun October 29, 1919.

${ }^{2}$ According to the 1910 census, Passaic was a city of 54,773 inhabitants. (Thirteenth Census of the United States, 1910, Statistics for New Jersey, Table 2, p. 579.) The "Legislative Annual, State of New Jersey," gives the estimate for 1915 as 61,225. The popular estimate for the current year is $\mathbf{7 2 , 0 0 0}$.
} 
ington that there is no possibility at present of the town growing beyond its present limits. The city is an interesting example of the average industrial city of the "one-dominant-industry" type. It has always been a textile town. The first cotton bleachery was established in 1813, although the real beginning in manufacturing was not until the Dundee Dam was erected in 1858. From that time until the pres. ent the city developed industrially until now it is one of the chief woolen manufacturing centers in the country.

Passaic is not an industrial town of rapid growth like Gary, Ind, or Flint, Mich.; on the contrary, it is an old town, founded in the seventeenth century in what is now called the Dundee section of the city, on the banks of the Passaic River. Unlike the brand-new industrial town, where social and educational problems as a result of industrial conditions are glaringly apparent to the most casual observer, conditions in Passaic which have given rise to its present social, industrial, and educational problems have grown up gradually and comparatively unnoticed until recent times, just as the city itself has crept up gradually about the original settlement of Dundee, choking it, and then spreading out across the railroad tracks to "the hill." But the majority of the people did not pass across the tracks; they remained on the east side of the city, until now Passaic presents the picture, so common in American industrial cities, of the separation of the mass of the people, largely foreign born, from the minority of the native born. Passaic is not unusual in this except that geographically the separation is unusually striking.

\section{WHERE THE MAJORITY OF THE PEOPLE LIVE.}

Apparently, as Passaic grew industrially, the factories tended to concentrate, as is usually the case, in the old part of the town, and the workers, as they arrived in response to the call of the mills, settled in the same section, until at the time of the 1910 census 76 per cent of the total population lived in wards 1 and 4 on the east side of the railroad track; 40.6 per cent lived in ward 1 alone, or the old Dundee section. In other words, nearly half of the total population lived in about one-sixth the total area of the city (280.5 acres), while 9.9 per cent lived in nearly half the total area of the city (783.9 acres), ward $3 ; 14.1$ per cent lived in ward $2 ;^{1} 22,266$ lived in ward 1 ; 7,719 in ward $2 ; 5,411$ in ward 3 ; and 19,377 in ward 4 (see map). Obviously, this means for the mass of the people very great congestion in a comparatively small area. 603

1 Thirteenth Census of the United States, 1910, Statistics for New Jersey, Table 5, p. 


\section{THE MAJORITY OF THE PEOPLE ARE FOREIGN BORN.}

The following chart (Chart I) shows that, of the total population 10 years of age and over in Passaic, 64.8 per cent were foreign born, ${ }^{1}$ and 87.6 per cent of the foreign born of all ages lived in wards 1 and $4,{ }^{2}$ i. e., on the east side of the Erie Railroad. In other words, the majority of the people of Passaic are foreign born, and they live in a little over one-third ( 660.8 acres) the total area of the city .

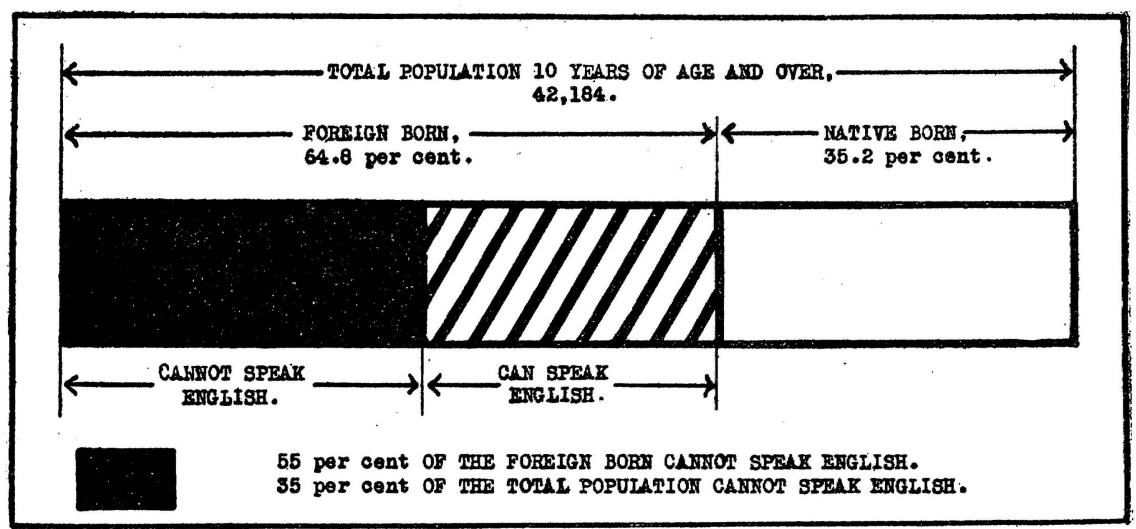

Chart I.-Per cent of total population of Passaic 10 years of age and over who are native born and who are foreign born; per cent of foreign born who can speak English.

These facts are brought out even more strikingly if only males of voting age are considered. In 1910 only 27 per cent of the total males of voting age were native born; 73 per cent of all males of voting age were foreign born, but only 20 per cent of them were naturalized (see Chart II) ; 75 per cent of all males of voting age lived on the east side in wards 1 and $2 .^{3}$ In other words, the great majority of potential voters in Passaic are foreign born, but only a small minority of them has, as yet, the right to vote.

\section{ILLITERACY, AND THE ABILITY TO SPEAK ENGLISH.}

In 1910 one out of every three people 10 years of age and over in Passaic $(15,107)$ could not speak English ${ }^{4} 55$ per cent of all the foreign born 10 years of age and over could not speak English. ${ }^{5}$ (See Chart I.) Moreover, when illiteracy was considered-and by illiteracy is meant inability to read or write any language-it was found that Passaic was one of the three cities in the United States

1 Thirteenth Census of the United States, 1910, Statistics for New Jersey, Table IV, p. 587 . 603.

2 Thirteenth Census of the United States, 1910, Statistics for New Jersey, Table V, p. 3 Ibid.

4 Thirteenth Census of the United States, 1910, Vol. I, Population, Table 22, p. 1282.

5 Thirteenth Census of the United States, 1910, Vol. I, Population, Tables 53 and 22, pp. 481 and 1282 . 
having the largest amount of illiteracy. (See Chart III.) When compared with other cities of the same size in New Jersey it was found that she led the most illiterate by six points. (See Chart IV.)
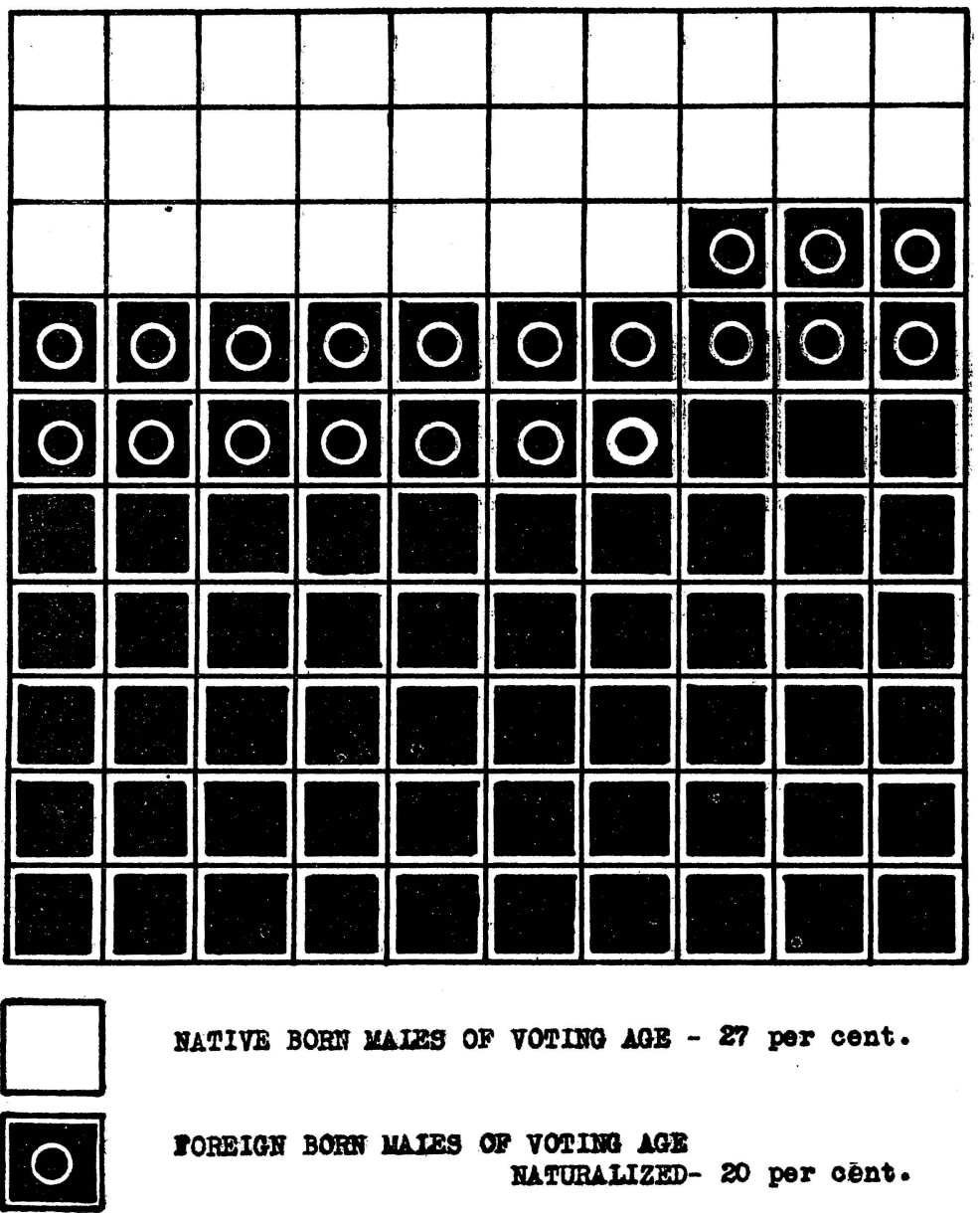

MATIVE BORN MAIZS OF VOTINO $\triangle A B$ - 27 per cent.

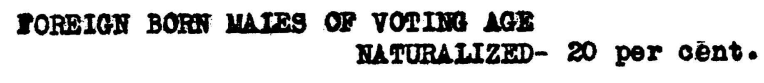

TOREIGN BOBN MATBS OF VORIHG $\triangle Q T$ MOT NATURALIZED- 53 per cent.

Chart II.-Per cent of males of voting age of Passaic who are native born and who are , foreign born (naturalized and not naturalized).

In 1910, of the total population of Passaic 10 years of age and over 15.8 per cent $(6,684)$ were illiterate, and 23.8 per cent $(6,523)$ of the foreign born 10 years of age and over were illiterate. ${ }^{1}$ (See Chart V.)

1 Thirteenth Census of the United States, 1910, Vol. I, Population, Table 35, p. 1252. 
The objection may be raised that these statistics are of little value at the present time, since they are 10 years old, but, as a matter of fact, it would seem fair to assume for the following reasons that they are not far from the truth.

\begin{tabular}{|c|c|c|c|c|c|c|c|c|c|c|c|c|}
\hline $\begin{array}{c}\text { Totalpc } \\
\text {. }\end{array}$ & $\begin{array}{l}\text { opulation } 10 \\
\text { years. of age } \\
\text { and over. }\end{array}$ & $\begin{array}{l}\text { Per } 1 \\
\text { cent. } 0\end{array}$ & 10 & 20 & 30 & 40 & 50 & 60 & 70 & 80 & 90 & 100 \\
\hline $\begin{array}{l}\text { Shenandoah } \\
\text { Borrough, } P_{a} .\end{array}$ & 18,764 & 23.7 & & & & & & & & & & \\
\hline Columbia, S.C. & 21,418 & 17.4 & & & & & & & & & & \\
\hline Passaic, N.J. & 42,184 & 15.8 & & & & & - & & & & & \\
\hline United States. & & 7.7 & & & & & & & & & & \\
\hline
\end{tabular}

Chart III.--The three cities with the greatest per cent of illiteracy.

\begin{tabular}{|c|c|c|c|c|c|c|c|c|c|c|c|}
\hline & $1 \%$ & 10 & 20 & 30 & 40 & 50 & 60 & 70 & 80 & 90 & 100 \\
\hline Passaic & 15.8 & & & & & & & & & & \\
\hline Perth Amboy. & 9.9 & & & & & & & & & & \\
\hline Bayonne. & $9: 1$ & & & & & & & & & & \\
\hline Elizabeth. & 6.9 & & & & & & & & & & \\
\hline Orange. & 6.6 & & & & & & & & & & \\
\hline Trenton. & 5.9 & & & & & & & & & & \\
\hline Hoboken. & 4.5 & & & & & & & & & & \\
\hline Atlantic City. & 4.5 & & & & & & & & & & \\
\hline Camden: & 4.4 & & & & & & & & & & \\
\hline $\begin{array}{l}\text { West Hoboken } \\
\text { Town. }\end{array}$ & 2.4 & & & & & & & & & & \\
\hline East Orange. & 1.3 & & & & & & & & & & \\
\hline United States. & 7.7 & & & & & & & & & & \\
\hline
\end{tabular}

Chart IV.-Per cent of illiterates in Passaic compared with other New Jersey cities of same size.

In the first place, as the Commissioner of Education pointed out in a bulletin "Public Facilities for Educating the Alien":

In 1910 there were in the United States more than thirteen millions of foreign-born men, women, and children, and more than four-fifths of those coming in that year were from southern and eastern European countries and other countries in which the percentage of illiteracy is very large. Nearly three millions of these foreign-born men, women, and children over 10 years of age were unable to speak the English language, and more than one million six hundred thousand were unable to read and write in any language. The four years following the census year of 1910 added largely to all these classes, the average immigration of these years being more than one million annually. The tide has receded since the beginning of the war in Europe. 
Passaic was one of the industrial centers which attracted the people from southern and eastern European countries. Therefore, it would be fair to assume that in the years from 1910 to 1914, there was a considerable increase in Passaic of the same type of immigration as in 1910, and that there was practically no increase from 1914 to the present time. On the contrary, there has doubtless been a decrease during the present year. Therefore, presumably, from 1910 to 1914 there was an increase in the number who could not speak English and in the amount of illiteracy. In 1910, however, the illiteracy in Passaic was twice as great as the illiteracy in the United States as a whole, and there were 15,107 people in the city who could

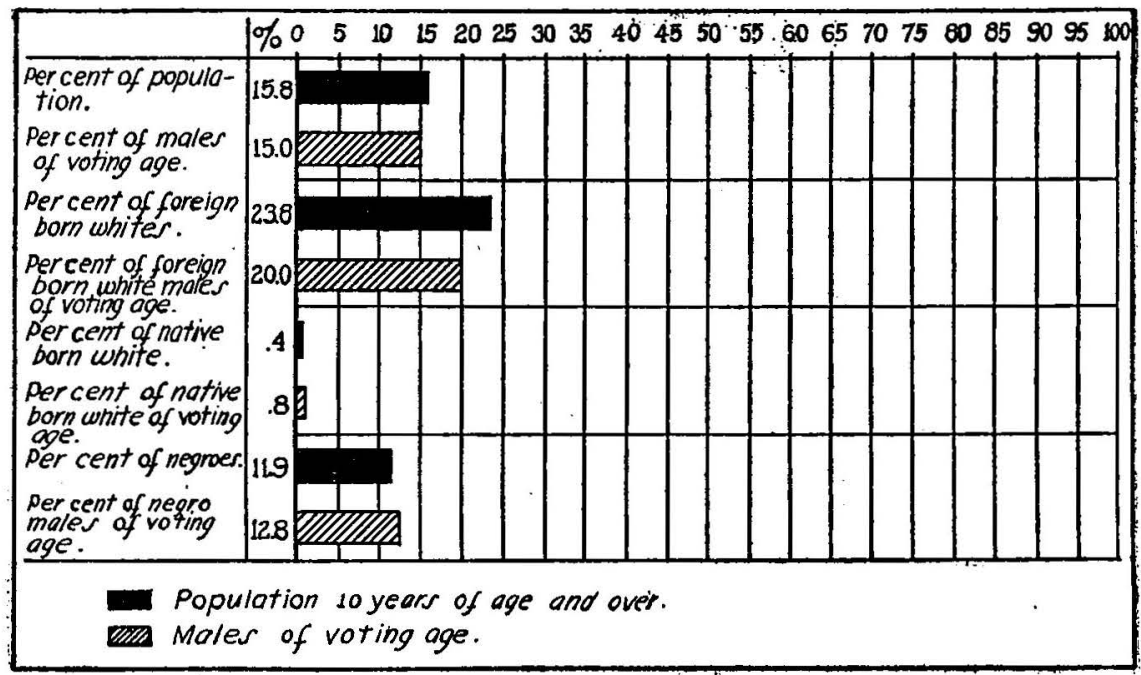

Chant V.-Fer cent of illiterates in the total population 10 years of age and over, and among males of roting age, in Passafc.

not speak English. From 1914 to the present time there has been, according to the records of the board of education, an average attendance at evening school classes for the teaching of English of not more than 250 persons per year. There are, of course, other agencies teaching English in Passaic, such as the Young Men's Christian Association and the Young Women's Christian Association, but on the most generous estimate not more than 200 per year average attendance could be credited to such classes. That means that since 1914 to 1920 about 450 people a year, or about 2,700 adults have attended classes which teach reading and writing. Therefore, assuming that the increase of population from 1910 to 1914 has been offset by emigration since the ending of the war, it is clear that not as much as one-fifth of those who could not speak English in 1910 has received training in that language in the last 10 years. In other words, there would still be at least 12,000 people in Passaic who can not speak English. 
THE PROBLEM OF ADULT EDUCATION IN PASSAIC, N. J. 11

\section{EIGHTY PER CENT OF THE PARENTS OF PUBLIC-SCHOOL CHILDREN ARE FOREIGN BORN.}

Moreover, in order to check the 1910 figures and to secure firsthand data in regard to present conditions, a questionnaire was sent out to the fathers and mothers of all public-school children to find out where they were born. As the returns were tabulated according to schools, it was possible to determine in what parts of the city the different nationalities lived. Replies were received from 14,623 parents of public-school children. Of this number, 80.8 per cent were foreign born and 19.2 per cent were born in the United States. Of all parents of elementary school children, 74.7 per cent live in wards 1 and 4 that is, on the east side of the Erie Railroad track;

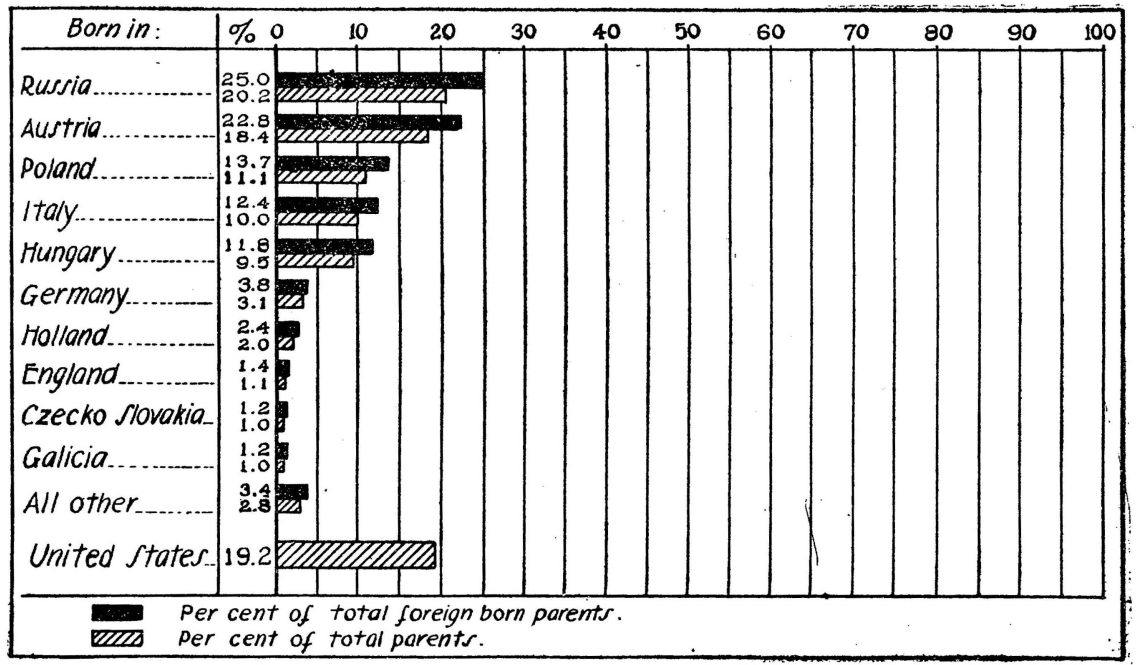

Chart VI.-Nativity of parents of public school children of Passaic.

26 per cent live in ward 1 , the Dundee section; 48.7 per cent live in ward $4 ; 18.7$ per cent in ward 2 ; and only 6.6 per cent in ward 3 . In other words, 74.7 per cent of all parents of public-school children live in hardly more than one-third of the total area of the town. Obviously, these figures tend to corroborate the statistics of 1910 as to the aistribution of population and nationality, the chief difference being that, although about the same proportion of the population remains on the east side of the city, there is a larger proportion or parents of public-school children in ward 4 than in ward 1 (see Table 1). Considering the fact, however, that there are a number of parochial schools in ward 1, the actual number of parents of children of public-school age in ward 1 is doubtless larger than these figures indicate.

Forty countries are represented among the parents of public-school children (see Table 1). The largest per cent are from the Slavic 
countries, and the next largest number from Italy. For example, as Chart VI shows, 20.2 per cent of all the parents of public-school children in Passaic were born in Russia; 25 per cent of all the foreign born are Russian; 18.4 per cent were born in Austria; 11.1 per cent in Poland; 11.8 per cent in Hungary ; 1.2 per cent in Czechoslovakia; 1.2 per cent in Galicia; and 12.4 per cent were born in Italy. Chart VII gives the distribution of nationalities according to schools and wards.

THE MAJORITY OF WORKERS ARE IN THE TEXTILE INDUSTRY.

It is difficult to determine the exact number of workers living in Passaic who work in Passaic factories, because, although Passaic, Garfield, and Wallington are politically separate towns, as a matter of fact they are industrially one unit, some factories having one part of their plant in Passaic and the other part in the adjoining town of Garfield, etc. According to the Board of Trade of Passaic, however, there are 94 industrial establishments in Passaic and the immediate vicinity giving the number of workers employed therein. There are in these establishments 28,749 workers. Of the total number, 19,140 , or 66.5 per cent, are in the textile industries, and 13,336 , or 46.4 per cent of all the workers, are employed in seven woolen mills, six of which are situated in or near the Dundee section of the city. (See Table 2.) 
THE PROBLEM OF ADULT EDUCATION IN PASSAIC, N. J.

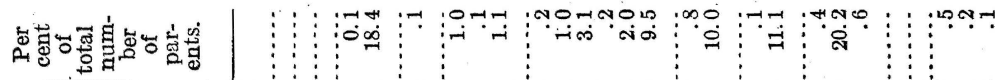

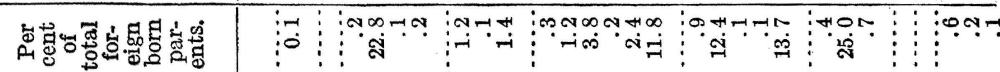

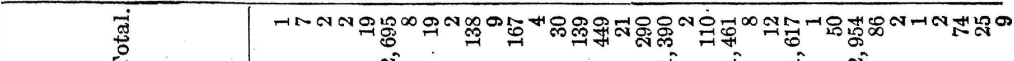

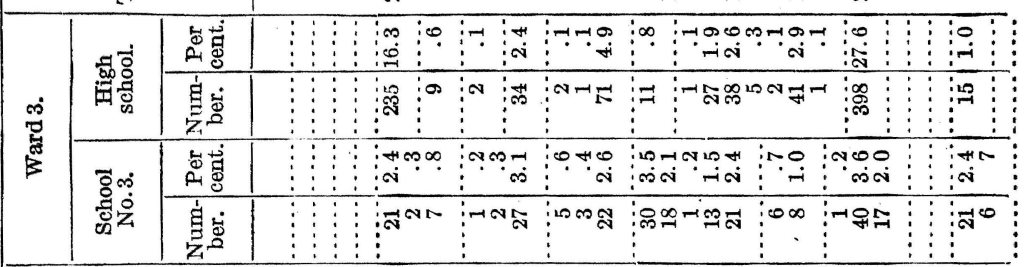

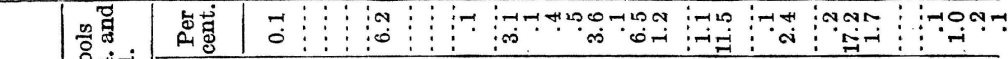

है

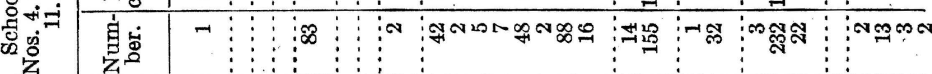

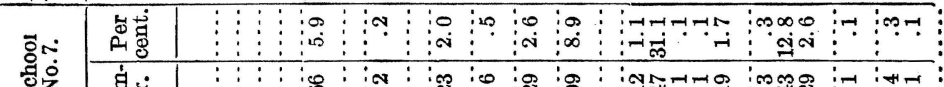
焉云

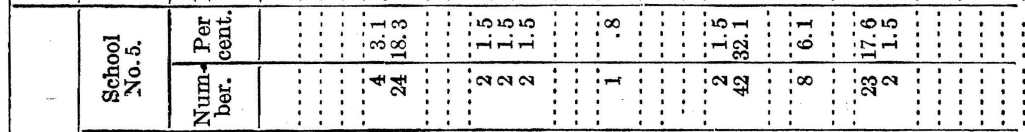

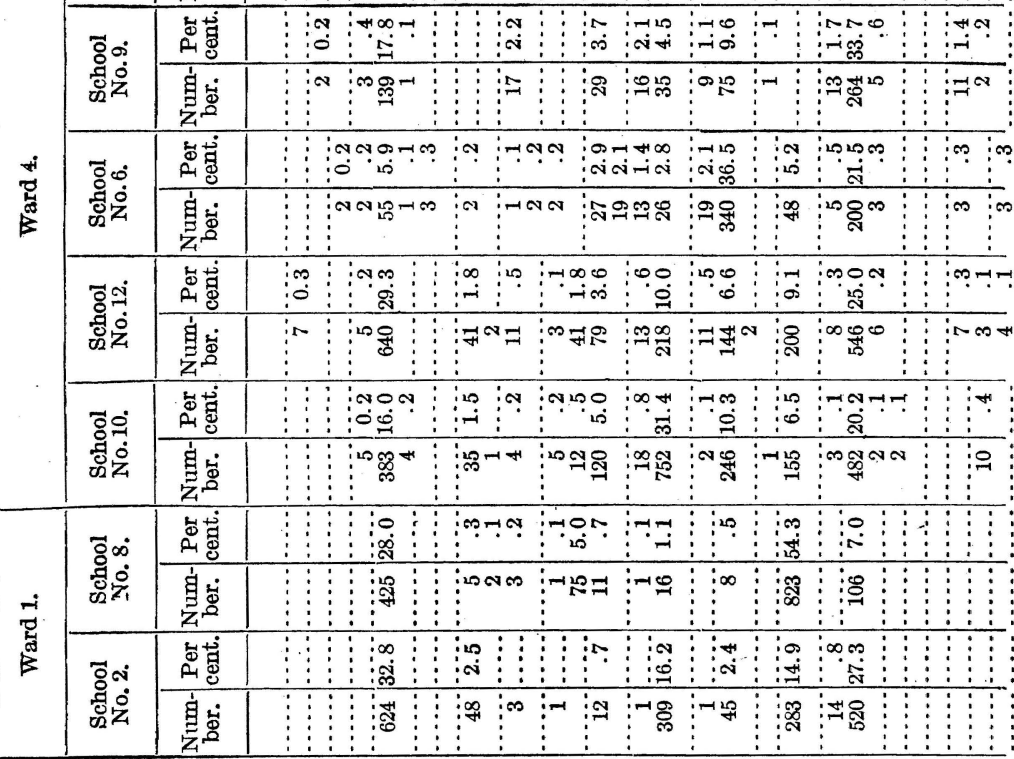


THE PROBLEM OF ADULT EDUCATION IN PASSAIC, N. J.

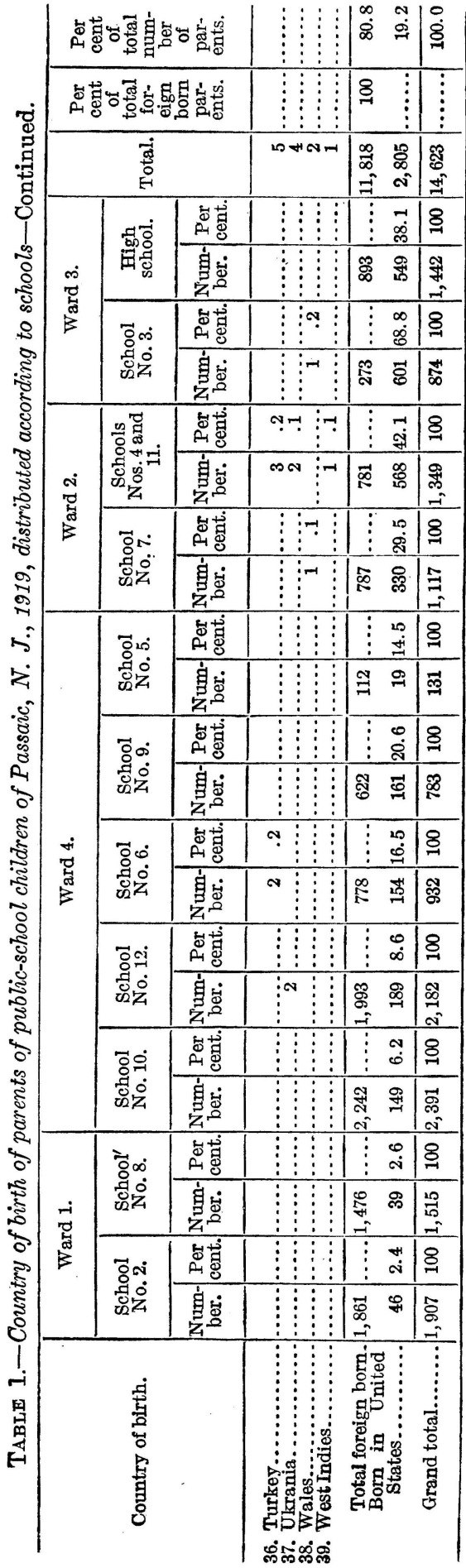

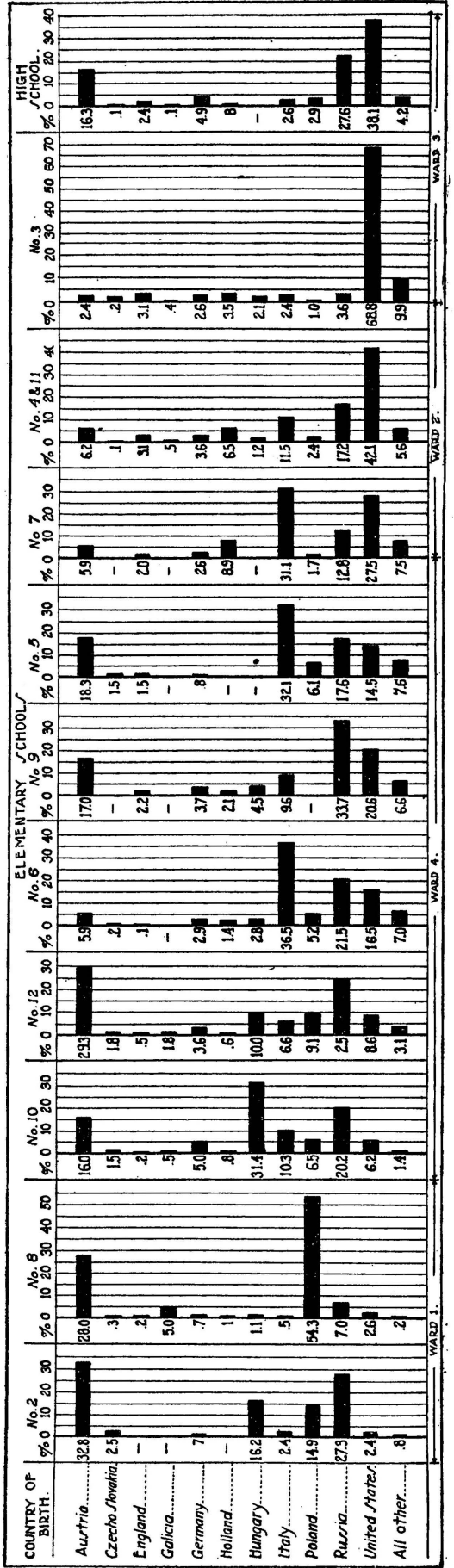


TABLE 2.-Tabulation of industries of Passaic, showing distribution of workers, 1919.

\begin{tabular}{|c|c|c|c|c|}
\hline Industries. & $\begin{array}{l}\text { Number } \\
\text { of men } \\
\text { workers. }\end{array}$ & $\begin{array}{l}\text { Number } \\
\text { of women } \\
\text { workers. }\end{array}$ & Total. & $\begin{array}{l}\text { Per cent } \\
\text { of total. }\end{array}$ \\
\hline 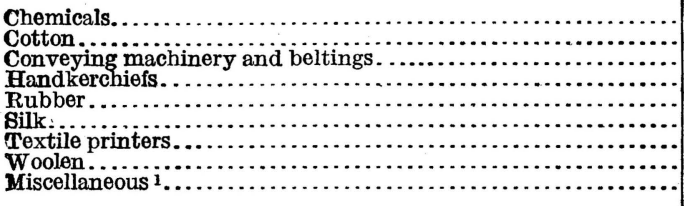 & $\begin{array}{r}385 \\
1,734 \\
452 \\
339 \\
2,148 \\
186 \\
643 \\
6,917 \\
4,532 \\
\end{array}$ & $\begin{array}{r}26 \\
974 \\
1,913 \\
175 \\
658 \\
90 \\
6,419 \\
1,158 \\
\end{array}$ & $\begin{array}{r}411 \\
2,708 \\
452 \\
2,252 \\
2,323 \\
844 \\
733 \\
13,336 \\
5,690 \\
\end{array}$ & $\begin{array}{r}1.4 \\
9.4 \\
1.6 \\
7.8 \\
8.1 \\
2.9 \\
2.6 \\
46.4 \\
19.8\end{array}$ \\
\hline Total. & 17,336 & 11,413 & 28,749 & 100.0 \\
\hline
\end{tabular}

1 Forty-eight establishments are represented in this list, but there are less than 3 establishments in each industry in this group.

\section{RELATION OF THE PRESENT SOCIAL AND INDUSTRIAL CONDI- TIONS OF PASSAIC TO THE PROBLEM OF ADULT EDUCATION.}

It is obvious from the foregoing facts that, inasmuch as the foreign born make up the majority of the people of Passaic, the first task of the public school in the matter of adult education is to meet the needs of the foreign-born adults. Let us consider what is already being done in this direction and what is the attitude of the people most concerned in the matter of adult education.

According to the reports of the board of education, 3,116 people attended evening classes for the teaching of English from 1915 to 1919 , but the average daily attendance for each of those years was only 249 pupils per year, as shown in the following table:

TABLE 3.-Enrollment and average attendance in public evening schools.

\begin{tabular}{|c|c|c|c|c|c|c|}
\hline . & Attendance. & $1915-16$ & 1916-17 & 1917-18 & $1918-1$ & Total. \\
\hline $\begin{array}{l}\text { Pupils enrol } \\
\text { A verage atte }\end{array}$ & & $\begin{array}{r}1,211 \\
468\end{array}$ & $\begin{array}{l}582 \\
203\end{array}$ & $\begin{array}{l}580 \\
188\end{array}$ & $\begin{array}{l}743 \\
137\end{array}$ & $\begin{array}{r}3,116 \\
249\end{array}$ \\
\hline
\end{tabular}

During the past year considerable effort has been put forth by various agencies outside the schools to increase the number of classes in English. Both the Young Men's Christian Association and the Young Women's Christian Association have had classes, but considering all the agencies, both inside and outside the schools, it is still obvious that only a small fraction of the people who are not able to speak English are receiving instruction in English. The most significant point about the figures of attendance at the public schools is that, although 3,116 people entered evening school in the four years from 1915 to 1919 , the average attendance for those years was only 996 , or about one-third of the number who entered. But since the same 996 people did not attend regularly, it follows that 
not even one-third of the people who entered had full-time instruction. In other words, the classes in English in the public evening schools are not attracting many pupils, and they are failing to hold them after they get the people to the schools.

It should be pointed out that this situation is not peculiar to Passaic. The city of Passaic is fortunate in having a progressive and up-to-date school system. It is also to be congratulated upon the fact that the city has the modern type of school buildings, which makes possible a socialized school for both children and adults, and these school buildings (Nos. 10 and 12) are situated in the section of the city where social centers are most needed. Passaic, with its progressive school policy, can develop an excellent system of adult education; the fact that the board of education has asked for a survey of the situation is evidence that it is interested in future accomplishments, not in defense of past failures. The fact is, however, that Passaic is in much the same position in regard to the development of adult education in which other cities find themselves; that is, a school plant equipped to take care of large numbers of students, a teaching force willing and eager to do its part, a large adult population, mostly foreign born, to whom the right kind of adult education would be a boon, and only a small number of people attending the evening classes.

Recently, since the interest in Americanization work, there has been a tendency throughout the country for various civic bodies, boards of trade, Young Men's Christian Associations, Young Women's Christian Associations, civic clubs, etc., to get together, form a committee, and lay out plans for increasing attendance at classes for the teaching of English; but the attendance still remains entirely out of proportion to the number of people to be reached. It is now generally recognized that one reason for this fact is that the group of people taking the initiative, praiseworthy as are their efforts, are, after all, not the group of people most concerned in the matter; that is, the men and women who attend or would be likely to attend such classes in the public schools. The bureau, therefore, in making the survey, followed its usual custom of endeavoring to find out from the people themselves, through their different clubs, foreign groups, and labor organizations, why they did not attend the evening schools and what kind of courses they would be interested in taking.

One of the first things revealed by the investigation was that the people, through their different nationality groups, had already started classes for teaching themselves English. This was particularly interesting in view of the fact that a number of public citizens interested in the subject of Americanization had stated as one of the reasons why so few people took courses in English that "the foreigners do not want to learn English." We are convinced that this is 
an erroneous impression, for in no case was there found any objection to learning English, and in many cases real eagerness to learn. It was found that the labor organization that had by far the largest number of foreign born, the Passaic Local of the Amalgamated Textile Workers of America, was already starting classes in English and citizenship and was planning to have classes in history, economics, etc. Such efforts, of course, are in line with the general movement among workers to start educational courses through trade-union colleges, workers' institutes, etc. Evidently, then, it was true in Passaic, as in other cities, that there was a desire on the part of the people for courses in English, and in a good many instances for more than the elementary courses in English. Why, then, were they not attending the evening schools in greater numbers?

\section{WHAT THE PEOPLE SAY IN REGARD TO THE EVENING SCHOOLS.}

The following are some of the reasons given by the men and women themselves, Poles, Russians, Hungarians, Bohemians. Austrians, as to why they did not attend evening school:

"How can I? I work at night."

"I work now during the day, but my wife works at night and I have to stay at home to take care of the children."

"I tried it; I learned to read and write some, but not to speak English."

"It is childish. We keep saying all the time, 'this is a desk;' 'this is a door.' I know it is a desk and a door. What for keep saying it all the time?"

"My teacher, she was very nice young lady, but very young. She does not understand what I want to talk about or know about."

“ 7.30 p. m. to 9.30 p. m. is too long; you get home too late. You get out of work at 5 , then get out of school at 9.30, and it's 10.30 before you get to bed, and that's too late for a spinner. A spinner can't take chances."

"They treat you like a child because you don't know English."

"Too tired."

In each of the interviews the people were asked if they would be more likely to come if they had teachers of their own nationality to teach them English. The response was immediate; their faces would light up as they replied, "Yes; that is different. Then we will not get discouraged in the beginning."

If these criticisms are carefully studied, it will be found that most of the fundamental reasons for the present failure in evening school instruction are touched upon in them. The criticisms are of three kinds-those that have to do with the method of instruction in the school; the attitude toward the foreign born, and conditions outside the school which make attendance difficult. 


\section{ENGLISH NOT TAUGHT AS A MEANS OF SOCIAL COMMUNICATION.}

In the first place, investigation proved that it was true that the method of instruction did not sufficiently take into consideration the people who were being taught. The recitation was not a "social recitation," and the inductive method was not used as a means of developing the course.

In the Passaic schools, at the time of the investigation, there were 395 pupils enrolled in the evening schools. There were 22 nationalities represented. The men and women enrolled were working during the day in 51 different establishments, the largest number being employed in the textile industry. Their ages ranged from 19 to 45 and over.

These pupils were grown men and women who, after a hard day's work, were giving up their evenings to come to school in order to learn to communicate in English. Yet, upon the whole, the chief criticism to be made of the evening school instruction is that the English language was not being taught for purposes of communication. The criticism of the workers that they were taught to read and write, but not to speak, was a well-founded criticism. Oral language is more important for the average person than the written or printed word; yet the large part of time in the classroom was taken up in reading and writing. And it should be mentioned at this point that there was little evidence of any sensitiveness to the sound of words on the part of the teachers. Pupils were permitted to enunciate badly, making the same mistake over and over again, without correction. There was a most unfortunate habit of reading in, chorus. This is, of course, a discredited method, particularly so in teaching adults a foreign language, since the best pupils lead in the chorus and the others are merely confirmed in their own bad habits of enunciation. There was almost no attempt to use the dramatic method of teaching; that is, having the pupils act out the written selections. There was almost no encouragement to discussion and little attempt to draw out the pupils and let them assist in carrying on the lesson. On the contrary, there was a very close adherence to the textbook, and at the same time a failure to follow the suggestions in the textbook as to methods of teaching. For example, in a lesson on "The newspaper," the directions were that the teacher should have a newspaper, and the pupils should read it, but as there was no newspaper in the class the lesson lost most of its value.

Also, it can not be denied that there was a tendency to treat the members of the class as though they were children. The attitude was kindly, but the tone of voice was not that of an equal addressing equals. Often the context of the lesson or the method of questioning was nothing short of absurd when it was remembered that it was 
adults who were receiving instruction; as, for example, "How many different things are there in the sky?" The answer was, "The sun, moon, stars, and clouds." Aside from the fact that the answer is not what might be called a comprehensive list of the "things in the sky," the lesson was taught without any graphic representation to insure that the pupils attached the right words to the right objects. Or again, in one class they read selections on "A coal mine," "The iron and steel industry," and "A packing house." Although there were men in the class who doubtless knew far more about these industries than the teacher, and although discussion on any one of them might have been used as a basis for testing how far the men had developed the art of communicating their ideas in English, no attempt was made to do anything but read each selection and pass on to the next.

The most serious criticism, however, was that with few exceptions there was no attempt at individual instruction. The pupils were taught as a class, instead of being divided into small groups and allowed to.progress according to their ability. There was little use of the inductive method in determining the needs of each individual in the class and in developing his power of communication.

As it happens, the best teaching of English which was observed was in a class of workers taught by an organizer of one of the labor organizations. The enunciation. was not always correct, but the spirit in the class was that of equals working out a problem together. There was the most thorough individual instruction, and an alertness on the part of the teacher in finding out the difficulties of each pupil and helping him to solve-them. The men were working hard, even doing home work for each lesson, and there was an atmosphere of mutual helpfulness that was most inspiriting.

\section{RELATION OF HOURS OF WORK TO EVENING SCHOOL INSTRUCTION.}

But even if the instruction was of the best possible type, there is another reason for the present failure to secure large numbers in evening schools for which the school is not responsible in any way, and which no amount of attraction on the part of the school can offset. We refer to the hours of work in the average industry and the prevalence of night work. Over and over again, as we have pointed out, when the workers were asked why they did not attend evening schools, the answer was a shrug and "How can I? I have night work," or "My wife works at night, I take care of the children." Consequently, we secured the hours of work of every person in the evening schools at the time of the investigation (with the exception of two small classes). Information was obtained from 207 pupils. 
They were in 41 different types of work. Of the 207 pupils, 136, or 65.7 per cent, worked from 8 hours to 8 hours and 40 minutes. Of these, 104 worked an 8 hour and 40-minute day, as the 48-hour week is the present standard in the textile industry of Passaic. It is an interesting fact that, of all the 395 who enrolled in evening schools this year, 54.2 per cent of those who stated their employment (304) were workers in the textile industry. A third of those from whom the hours were secured worked 9 hours and over. Twenty-six worked 9 hours, and 34 worked from $9 \frac{1}{2}$ to 10 hours.

It is only the exceptional person who, after a 10-hour day, will come to evening school for 2 hours' hard work on learning a new language. Nor can it be expected that large numbers of those having an 8-hour and 40-minute day will have the energy to attend school in the evening. But even this is not as great a handicap as the intermittent night work which unexpectedly cuts into the attendance in classes throughout the school, taking a dozen workers from one class, half a dozen from another, etc. The pupils in evening school when asked about night work, replied " Any time may work nights," "Last year worked nights 12 weeks straight," "I work two weeks day work, one week night work," or "May go on night shift next week, or overtime to 6 or 7 o'clock," or "I work four weeks day work, one week night work," or "Can't tell when we are going to have night work."

That was the point; they couldn't tell when they were going to have night work, and this uncertainty plays havoc with the administration of the school. No factory with a working force, say of 2,000 , would undertake to get out production if suddenly 500 left one week and didn't come back for four weeks, and 200 more left just before the 500 came back, and didn't come back for 12 weeks, etc. Administratively, it would be an impossible proposition, and yet that is exactly the administrative proposition that is being put up to the schools at the present time. There is a great deal of agitation for the teaching of English and the extension of adult education, but the schools can not be expected to function successfully in this matter when industrial conditions undermine the effectiveness of the work of the schools, as is the case at present.

Recognizing this fact the bureau took up with the manufacturers in Passaic the question of releasing the workers during the day without loss of pay to attend classes in English in the public schools. At least two of the largest woolen manufacturers have already agreed to release their workers who wish to learn English at 4.30 in the afternoon with pay from 4.30 to 5 (which is the end of the day shift in the woolen mills) on consideration that the workers will give until 5.30 to the lessons. The proposition was also taken up with the workers, and although not all the nationalities could 
be seen, those groups who were interviewed stated that they considered the proposition fair and would be glad to attend the public schools to learn English from 4.30 to 5.30 p. m. Passaic is to be congratulated upon the fact that it has manufacturers and workers who are willing to make this arrangement, and also that it has schools sufficiently near the mills to make such an arrangement feasible.

\section{METHOD OF APPROACH TO THE PROBLEM OF ADULT EDUCATION PSYCHOLOGICALLY UNSOUND.}

But even this arrangement will not succeed unless the whole method of attracting people to the public schools is changed. The chief lesson to be learned from the interviews with the different nationalities and from the study of the social and industrial conditions is that the present method of approaching the problem of adult education is psychologically unsound; that is, the tendency has been to work out plans for the people, not with them. It is the old story of endeavoring to work changes from the top down instead from the bottom up. Such a method can not produce enduring results, since no plan for educational progress can be ultimately successful unless it has its roots in the intelligent understanding of the masses of the people. If the schools are to function in the lives of the people, they must be sensitive to the people's needs, but that is not possible except by establishing a means of connection with the people so that they may make their needs and desires known.

This is true in general for the whole country, but its application to a city like Passaic is particularly obvious. In the early days in this country, the school was a social gathering place for the people, and all the people in the community knew that the schools belonged to them and were for their use. But at the present time the case is different. In a city like Passaic, where the large number of people are foreign born and from countries which do not have public school systems founded on the same principles as those of America, the bulk of the people who should be attending the schools have no comprehension of the fact that the schools belong to the people and should grow and change in accordance with their needs. They do not even know that if a certain number of people ask for a course in any subject, the schools must provide such a course. The school is to them a public institution which spells authority; they do not think of it as a place to go to for recreation and instruction and inspiration. They do not think of it as a place in which they can expand and grow, but rather as a place in which they must conform, and above all they do not think of it as their institution which they are responsible for developing until it adequately meets the needs of all the people. 


\section{ADULT EDUCATION A SOCIAL PROBLEM.}

In other words, the adult education problem is fundamentally a social problem. It is not enough that the school open its doors to the people. It is necessary that the school go to them and make them eager to learn what the school has to teach; and it can do this only by rousing their support and confidence and their interest in sharing in the responsibility of developing the school.

Moreover, in Passaic the social and industrial situation is such that a special effort needs to be put forth to enlist the confidence of the people and to make them realize what part the public schools can play in their lives. As was pointed out in the beginning of this report, there is an unfortunate separation of the foreign-born group and the native born. The geographical separation is obvious, but to anyone only slightly acquainted with the city the spiritual separation, the lack of connection between the two groups, is even more striking. At present 80.8 per cent of all parents of public-school children are foreign born and over 83.9 per cent of all the foreignborn parents live in about one-third of the city, while the remaining minority of the population live in the other section of the city, separated by different traditions, different ideals, and different habits of living, of working, and of enjoying life. It appears to be a matter of common consent among the more thoughtful citizens that one-fourth of the people do not know what the other threefourths are thinking and feeling, and upon the whole there has been little successful effort to bridge the chasm by developing mutual understanding and respect. The result has been a lack of understanding and a growth even of suspicion and distrust which is most unfortunate.

Doubtless the inability of the different nationalities to communicate with each other by means of a common language is one important source of misunderstanding; and yet it was found that this misunderstanding had actually progressed so far that there was a real skepticism among some citizens as to the desire of the foreign groups to learn English, and even a dread of letting them come to the schools to study English for fear of the use that they might make of it. This is, of course, an extreme instance of the lack of mutual confidence and trust; it is not typical, but it is significant as showing the difficulties to be met.

\section{ESPIONAGE SYSTEM CREATES DISTRUST.}

Moreover, as a result of various industrial disputes this distrust has without doubt been intensified by the development among certain mills of a most unfortunate type of espionage system over the workers which could not help but undermine continually any possible development of mutual trust and confidence among the people of Passaic. 
Fortunately, however, it is understood that this undesirable system of espionage is to be abolished. If true, it is highly important from an educational standpoint, for since education is a social process and can not function as a thing apart from the general social and industrial situation, and since adult education in particular is dependent for its success upon a spirit of social cooperation and mutual confidence, it is obvious that the continuance of such a system of espionage which creates an atmosphere of suspicion and distrust would make the successful growth of adult education out of the question. Consequently, it is most fortunate if a more farsighted and statesmanlike policy, of which there are many evidences in Passaic, plans to eliminate such a source of friction and distrust.

It should, however, be clearly understood by the people of Passaic that, so long as an espionage system so subversive of mutual trust and social confidence among the adult population of Passaic continues the educational process is impossible.

\section{RECOMMENDATIONS.}

As a result, then, of the investigation the bureau makes the following recommendations:

I. A separate department of adult education.-Up to the present time adult education has been carried on in evening schools as a sort of adjunct to the day school, and the staff has been largely made up of already overworked day-school teachers. This was not a matter of great importance 25 or 50 years ago, but now the problem of adult education has assumed such proportions and is of such vital importance to the welfare of the community that it warrants the creation of a separate department with a separate staff of workers.

Staff: There should be a director and one assistant and clerical assistance.

Hours: The hours of work of the adult education staff should be from 1 p. m. to 10 p. m.

Purposes: The object of creating such a department would be, in the first place, to insure the undivided attention of a group of experts on the problem of adult education. In the second place, the director would be responsible for building up the work through the cooperation of the people. This would necessitate getting into personal contact with all the different nationality groups, labor-union organizations, clubs, etc., speaking at their meetings, explaining the purposes of the adult education department, getting their criticisms and suggestions, and asking each of them to elect a delegate to a central advisory committee.

II. An advisory council.-There should be an advisory council made up of representatives elected by the different nationalities, 
labor organizations, clubs, etc., which should assist the adult education department in developing the schools in accordance with the demands of the people. These representatives on the council would be responsible for making the plans of the adult education department known to the different nationality and labor-union groups, enlisting their interest, getting criticisms and statement of desires in regard to courses, etc., and thus keeping the adult education department in touch with the needs of the people.

III. Courses in the adult education department.-Inasmuch as the courses will be developed in connection with the demands of the people, it would be inconsistent to lay out any hard and fast plans for such courses, but the investigation tended to show that the people want the following courses:

(a) A course for training teachers of the different nationalities to teach their own people English.

It was very evident that the different foreign groups in Passaic would be much more likely to attend evening school if they could be taught by people of their own nationality. Whatever may be the arguments from a pedagogical standpoint as to the relative value of a teacher of native birth or foreign birth teaching English, as a matter of fact, there is no question that in Passaic the large number of foreign born would be more likely to attend English classes if they could be taught by people of their own nationality. As they expressed it, they would not get discouraged in the beginning. The difference in the enrollment and attendance numbers shows how important it is to eliminate the various elements which make for that "discouragement in the beginning." It might be possible to follow a plan sometimes employed in universities of having a native teacher and a foreign teacher each teach one group twice a week. Under such a plan the foreign teacher explains the idiomatic phrases in terms that the foreign group would know, and the native-born American could teach the grammatical construction, etc. In order to make it possible for these specially trained teachers to teach in the evening schools, it would be necessary to take up with the State commissioner the question of changing the regulations in regard to the requirements for teaching in evening school.

(b) Day courses.-There should be day courses for the teaching of English to beginners from 4.30 to 5.30 p. m. As has been pointed out earlier in the report, certain manufacturers are willing to release their workers at 4.30 without loss of pay to take up such courses, and it is probable that many others would be willing to make such an arrangement. The director of adult education should make announcement of this plan to the advisory council, and the representatives in that council should carry the information to their different nationality and labor-union groups. It is important that the an- 
nouncement should come this way rather than through the employers. The director would have to send records of attendance to the mills so that the arrangement for payment for the half hour in school could be made.

(c) Evening courses.-The evening courses would probably divide themselves as follows:

(d) Advanced courses in English or in history, economics, etc. One reason, probably, why adults do not stay longer in evening school is because there is nothing to look forward to. Yet the movement in labor unions for workers' institutes and trade-union colleges, with courses in history, economics, law, sociology, etc., is evidence of how great a desire there is for more advanced courses. There is no reason why such courses should not be given in public schools whenever enough students request them. Doubtless it would be possible to secure university professors to give these courses, as is done in the university tutorial classes in England, and in certain of the workers' institutes in this country.

(2) Courses in science', art, shop, etc. The schools in the part of the city where the largest number of people would attend evening school-public schools Nos. 10 and 12-are of the modern type, equipped with laboratories and studios. The present evening classes in science, mechanical drawing, etc., could easily be extended as the demand grew.

(3) Recreation, athletics, etc. If adult education is really to function in the lives of the people the schools must become the people's clubs, where they may hold their meetings and entertainments and where they may get the opportunity for athletics, etc. Fortunately public schools Nos. 10 and 12 are well equipped to meet these demands, and already much is being done in this respect. With a department of adult education, there is no reason why all these facilities should not be in use all the time by all the people in the neighborhood.

\section{CONCLUSION.}

In conclusion, it should be emphasized again that education is a social process. The adult education problem is a social problem. If it is to be worked out successfully, it must be developed through the intelligent understanding and cooperative responsibility of all the people. If there is any tendency to bring pressure to bear to refuse any individual or group of individuals the opportunity to learn English for fear of the opinions which they may express when they can express them in English; if there is an atmosphere of distrust and skepticism outside the schools as to the sincerity of the desire of the majority to learn English; if espionage displaces the community benefits of rational freedom; if the attempt is made to 
dievelop the schools for the people instead of with the people, then there is no hope of developing an adequate system of adult education in Passaic. If, on the other hand, it is remembered that the public-school system in America was created by the people for the use of all the people, and if the more liberal spirit of social cooperation, confidence, and desire for mutual understanding, which it is believed is the true spirit of Passaic, prevails, then there is every reason why Passaic may develop a system of adult education which would not only solve her own problems but also serve as a model for other industrial cities. 



